\title{
PENGAWASAN TERHADAP PEREDARAN MAKANAN IMPOR YANG TIDAK BERSERTIFIKASI HALAL OLEH BADAN PENGAWAS OBAT DAN MAKANAN (BPOM)*
}

\author{
Oleh : \\ Pande Ratih Anggaraini Giri Putri ${ }^{* *}$ \\ Dr. I Ketut Westra, SH., $\mathrm{MH}^{* * *}$ \\ Ida Bagus Putu Sutama, SH., M.Si ${ }^{* * * *}$ \\ Hukum Bisnis Fakultas Hukum Universitas Udayana
}

\begin{abstract}
ABSTRAK
Produk impor selama ini memang diyakini oleh sebagian besar masyarakat Indonesia sebagai produk yang mempunyai kualitas unggul, karena disertai dengan persyaratan-persyaratan yang sudah standar mengenai proses produksi, packaging, maupun pemasarannya. Realitanya, ada beberapa produk impor yang tidak memenuhi standar persyaratan, sehingga produk impor yang dibeli konsumen berkualitas rendah, bahkan membahayakan keselamatan konsumen.

Jenis penelitian yang digunakan dalam penelitian ini yakni penelitian hukum yuridis empiris yang mengkaji kesenjangan antara ketentuan pangan impor bersertifikasi halal di BPOM dengan pelaksanaannya di lapangan. Penelitian ini memiliki dua tujuan. Pertama, untuk mengetahui pola pengawasan yang dilakukan Badan Pengawas Obat dan Makanan (BPOM) terhadap peredaran makanan impor yang tidak bersertifikasi halal. Kedua, untuk mengetahui upaya-upaya yang dilakukan BPOM dalam melakukan pengawasan terhadap peredaran makan impor yang tidak bersertifikasi halal.

Hasil penelitian ini menunjukkan bahwa pengawasan yang dilakukan BPOM belum berjalan secara efektif karena faktanya

\footnotetext{
* Makalah ilmiah ini disarikan dan dikembangkan lebih lanjut dari Skripsi yang ditulis oleh penulis atas bimbingan Pembimbing Skripsi I Dr. I Ketut Westra, SH., MH dan Pembimbing Skripsi II Ida Bagus Putu Sutama, SH., M.Si.

** Penulis Pertama : Pande Ratih Anggaraini Giri Putri adalah mahasiswa Fakultas Hukum Universitas Udayana.

*** Penulis Kedua : Dr. I Ketut Westra, SH., MH, adalah Dosen Fakultas Hukum Universitas Udayana.

**** Penulis Ketiga : Ida Bagus Putu Sutama, SH., M.Si, adalah Dosen Fakultas Hukum Universitas Udayana.
} 
masih ditemukan produk makanan impor yang tercemar dengan DNA babi (porcine) pada proses produksinya meskipun telah memiliki izin untuk di distribusikan di Indonesia. Dalam menjalankan perannya di bidang pengawasan obat dan makanan BPOM memiliki kendala internal dan eksternal. Upaya-upaya yang dilakukan BPOM dalam menanggulangi kendala-kendala yang dihadapi antara lain sosialisasi, kerjasama dengan institusi lainnya dan dikeluarkannya public warning.

\title{
Kata kunci: Pengawasan, BPOM, Makanan Impor, Sertifikasi Halal
}

\begin{abstract}
Imported products have been believed by most Indonesians as products that have superior quality, because they are accompanied by standard requirements regarding the production process, packaging, and marketing. In reality, there are some imported products that do not meet the standard requirements, so imported products that consumers buy are of low quality, even endanger the safety of consumers.

The type of research used in this study is empirical juridical legal research that examines the gap between the provisions of imported food halal certified at BPOM and its implementation in the field. This study has two objectives. First, to find out the pattern of supervision by the Food and Drug Supervisory Agency (BPOM) on the circulation of imported food that is not halal certified. Secondly, to find out the efforts made by BPOM in supervising imported food circulation that is not halal certified.

The results of this study indicate that the supervision carried out by BPOM has not been running effectively because of the fact that imported food products that were contaminated with pig DNA (porcine) were found in the production process even though they already had permission to be distributed in Indonesia. In carrying out its role in the field of drug and food supervision BPOM has internal and external constraints. BPOM's efforts in overcoming the obstacles faced include socialization, cooperation with other institutions and the issuance of public warnings.
\end{abstract}

Keywords: Controlling, Drug and Food Supervisory Agencies, Imported Foods, Halal, Certification

I. Pendahuluan 


\subsection{Latar Belakang}

Pangan telah menjadi kebutuhan dasar manusia yang paling utama dan pemenuhannya merupakan bagian dari hak asasi manusia sebagai komponen dasar untuk mewujudkan sumber daya manusia yang berkualitas. Negara juga memiliki kewajiban dalam mewujudkan ketersediaan, keterjangkauan, dan pemenuhan konsumsi pangan yang cukup, aman, bermutu, dan bergizi seimbang. ${ }^{2}$

Saat ini banyak sekali ditemui produk-produk dari luar negeri yang beredar di Indonesia, khususnya makan dan minuman siap saji atau biasa disebut instan. Semakin banyak produk makanan dan minuman dengan berbagai merk dan jenisnya, sering kali ditemukan produk yang dalam produksinya tercemar dengan DNA babi yang merugikan konsumen khusunya bagi konsumen Muslim.

Berdasarkan laporan yang diberikan oleh Badan Pengawas Obat dan Makanan (BPOM, mengatakan bahwa pada tahun 2017 pihaknya telah mencabut izin edar produk impor berupa mi instan asal Korea karena proses produksinya yang tidak halal dan menyebabkan tercemarnya produk tersebut dengan DNA babi. ${ }^{3}$

Pada kenyataannya, dapat dilihat kesenjangan antara das sollen dan das sein, antara peraturan perundang-undangnan dengan kenyataan di lapangan. Produk impor yang selama ini diyakini lebih unggul karena untuk memasukan produk tersebut ke Indonesia disertai dengan bebrbagai persyaratan namun pada

3 Edy Nurcahyo, 2018, "Pengaturan dan Pengawasan Produk Pangan Olahan", Jurnal Magister Hukum, Fakultas Hukum Universitas Udayana, h. 413.

3 Jabbar Ramdhani, Detik News, 2017, "BPOM: Ada importir Mi Samyang Dicabut Izin Edarnya Januari Lalu”, URL: https://news.detik.com/berita/d-3535433/bpom-ada-importir-mi-samyangdicabut-izin-edarnya-januari-lalu diakses pada tanggal 3 November 2017. 
nyatanya dapat merugikan atau bahkan membahayakan konsumen juga.

1.2 Rumusan Masalah

1. Bagaimanakah pelaksanaan pengawasan yang dilakukan Badan Pengawas Obat dan Makanan (BPOM) terhadap makanan impor yang tidak bersertifikasi halal?

2. Bagaimanakah upaya-upaya yang dilakukan Badan Pengawas Obat dan Makanan (BPOM) dalam melakukan pengawasan terhadap peredaran makanan impor yang tidak bersertifikasi halal?

\subsection{Tujuan}

Tujuan daripada penulisan jurnal ini adalah untuk mengetahui dan memahami pola pengawasan yang dilakukan BPOM di Denpasar terhadap peredaran makanan impor yang tidak bersertifikasi halal.

II. Isi Makalah

\subsection{Metode Penelitian}

Metode yang digunakan dalam penulisan jurnal ini adalah menggunakan metode yuridis empiris dengan pendekatan perundang-undangan (statute approach), pendekatan fakta (fact approach), dan pendekatan analisis (analytical approach). Pendekatan secara yuridis yaitu dengan melihat dari segi-segi hukum sesuai dengan peraturan perundang-undangan yang berlaku. 4 Sedangkan pendekatan empiris yaitu pendekatan masalah dengan melakukan penelitian di lapangan. Sehingga

${ }^{4}$ Bahder Johan Nasution, 2008, Metode Penelitian Ilmu Hukum, Mandar Maju, Bandung, h. 36. 
metode penelitian Yuridis Empiris yakni, metode penelitian hukum yang meneliti secara nyata, bagaimana bekerjanya hukum di lingkungan masyarakat. ${ }^{5}$ Jenis penelitian ini merupakan salah satu cara yang dapat ditempuh untuk mendapatkan kebenaran, yaitu dengan membandingkan aturan yang ada dengan pelaksanaannya atau kenyataan dalam masyarakat (dasollen dan dassein). Oleh karena sifat penelitian ini adalah deskriptif maka data dan sumber data yang digunakan disini ialah data primer berupa informasi dari para informan, sedangkan data sekunder adalah bahan hukum yang meliputi bahan hukum primer berupa peraturan perundang-undangan sedangkan bahan hukum sekunder adalah literatur berupa buku, dll. ${ }^{6}$

\subsection{HASIL DAN PEMBAHASAN}

\subsubsection{Pengawasan BPOM Atas Beredarnya Produk Makanan Impor Yang Tercemar dan Tidak Bersertifikasi Halal}

Berdasarkan Pasal 2 pada Peraturan Presiden Nomor 80 Tahun 2017 tentang Badan Pengawas Obat dan Makanan, tugas umum BPOM adalah7:

(1) BPOM mempunyai tugas menyelenggarakan tugas pemerintahan di bidang pengawasan Obat dan Makanan sesuai dengan ketentuan peraturan perundang-undangan.

(2) Obat dan Makanan sebagaimana dimaksud pada ayat (1) terdiri atas obat, bahan obat, narkotika, psikotropika,

5 I Made Pasek Diantha, 2016, Metodologi Penelitian Hukum Normatif dalam Justifikasi Teori Hukum, Prenada Media, Jakarta, h.29.

${ }^{6}$ Amirudin dan H.Zainal Asikin, 2010, Pengantar Metode Penelitian Hukum, Jakarta: PT. Raja Grafindo Persada, h. 25.

${ }^{7} \mathrm{Ibid}$. 
prekursor, zat adiktif, obat tradisional, suplemen kesehatan, kosmetik, dan pangan olahan.

Semakin maraknya produk makanan impor makanan impor yang tidak bersertifikasi halal yang tercemar dengan DNA babi (porcine), maka BPOM Kota Denpasar diberikan wewenang untuk melakukan perlindungan kepada masyarakat selaku konsumen dengan melakukan pengawasan terhadap peredaran makanan impor.

Pola pengawasan yang dilakukan BPOM diatur dalam Pasal 3 Peraturan Presiden No. 80 Tahun 2017 Tentang Badan Pengawas Obat dan Makanan yang menyebutkan bahwa:

(1) Dalam melaksanakan tugas pengawasan Obat dan Makanan, BPOM menyelenggarakan fungsi:

a. penyusunan kebijakan nasional di bidang pengawasan Obat dan Makanan;

b. pelaksanaan kebijakan nasional di bidang pengawasan Obat dan Makanan;

c. penyusunan dan penetapan norrna, standar, prosedur, dan kriteria di bidang Pengawasan Sebelum Beredar dan Pengawasan Selama Beredar;

d. pelaksanaan Pengawasan Sebelum Beredar dan Pengawasan Selama Beredar;

e. koordinasi pelaksanaan pengawasan Obat dan Malanan dengan instansi pemerintah pusat dan daerah;

f. pemberian bimbingan teknis dan supervisi di bidang pengawasan Obat dan Makanan;

g. pelaksanaan penindakan terhadap pelanggaran ketentuan peraturan perundang-undangan di bidang pengawasan Obat dan Makanan; 
h. koordinasi pelaksanaan tugas, pembinaan, dan pemberian dukungan administrasi kepada seluruh unsur organisasi di lingkungan BPOM;

i. pengelolaan barang milik/ kekayaan negara yang menjadi tanggung jawab BPOM;

j. pengawasan atas pelaksanaan tugas di lingkungan BPOM; dan

k. pelalsanaan dukungan yang bersifat substantif kepada seluruh unsur organisasi di lingkungan BPOM.

(2) Pengawasan Sebelum Beredar sebagaimana dimaksud pada ayat (1) adalah pengawasan Obat dan Makanan sebelum beredar sebagai tindakan pencegahan untuk menjamin Obat dan Makanan yang beredar memenuhi standar dan persyaratan keamanan, khasiat/ manfaat, dan mutu produk yang ditetapkan.

(3) Pengawasan Selama Beredar sebagaimana dimaksud pada ayat (1) adalah pengawasan Obat dan Makanan selama beredar untuk memastikan Obat dan Makanan yang beredar memenuhi standar dan persyaratan keamanan, khasiat/manfaat, dan mutu produk yang ditetapkan serta tindakan penegakan hukum.

Disamping pola pengawasan yang dikutip dari situs web BPOM secara spesifik berdasarkan wawancara dengan Dra. Luh Putu Witariathi, Apt. sebagai Kepala Bidang Sertifikasi dan Layanan Informasi Konsumen, pada tanggal (16 April 2018) menyebutkan bahwa pengawasan yang dilakukan BPOM terdiri dari beberapa pola, yakni:

a. Sistem pengawasan produsen

Sistem pengawasan produsen terbagi menjadi empat (4) yaitu: 


\section{a.1 Good Manufacturing Practices (GMP)}

Good manufacturing practices adalah cara produksi yang baik, terdapat beberapa kategori dalam pemenuhan cara produksi yang baik, antara lain:

\section{Peralatan Produksi}

Peralatan produksi harus terbuat dari bahan yang kuat dan tidak mudah untuk berkarat serta mudah dibersihkan.

2. Pengendalian Proses

Dalam melakukan produksi untuk menghasilkan suatu produk yang bermutu dan aman makan harus dilakukan pengendalian proses produki, dengan cara sebagai berikut; penetapan bahan baku,penetapan komposisi, penetapan cara produksi, penetapan kemasan dan penetapan keterangan lengkap mengenai produk.

3. Label Pangan

Label pangan harus jelas dan informatif sehingga memudahkan konsumen untuk menyimpa, mengelola dan mengkonsumsi. Label pangan sekurang-kurangnya harus berisi nama produk, bahan yang digunakan, berat bersih, tanggal, bulan dan tahun kadaluwarsa dan nomor sertifikasi produk.

4. Penarikan Produk

Penarikan produk dilakukan apabila suatu produk diduga sebagai penyebab timbulnya penyakit atau keracunan pangan. Hal ini bertujuan untuk mencegah timbulnya korban yang lebih banyak lagi.

a.1 Pre market 
Pre market merupakan pengawasan pendahuluan yang dilakukan sebelum suatu produk beredar di masyarakat. Tahapan yang dilakukan antara lain; sertifikasi, registrasi dan distribusi produk. Pre market diantaranya dilakukan saat pelaku usaha/importer mengurus pendaftaran di BPOM dan saat pemeriksaan kelengkapan dan keabsahan dokumen dan barang di pintu gerbang pelabuhan/bandara yang dilakukan oleh petugas Bea dan Cukai. ${ }^{8}$

\section{a.2 Post market}

Post market merupakan pengawasan yang dilakukan sestelah suatu produk beredar di masyarakat. Pengawasan ini dilakukan dengan melakukan inspeksi ke pasar, supermarket maupun toko retail lainnya untuk mengambil sampel makanan yang dicurigai berbahaya bagi masyarakat dan kemudian diujikan ke laboraturium.

\section{b. Sistem Pengawasan Pemerintahan}

Dalam sistem ini, BPOM membagi kegiatan pengawasan dalam tujuh (7) kategori, antara lain sebagai berikut:

1. Regulasi

Pengawasan yang dilakukan BPOM dilakukan berdasarkan peraturan perundang-undangan yang berlaku. Dalam melakukan pengawasan makanan BPOM mengacu kepada UU Pangan.

2. Standarisasi

Standarisasi yaitu mengenai takaran zat-zat yang digunakan dalam pembuatan makanan maupun ukuran spesifik bentuk daripada makanan tersebut

3. Registrasi

8 Nurhayati, 2009, "Efektivitas Pengawasan Badan Obat dan Makanan", Jurnal Hukum, Fakultas Hukum Universitas Gajah Mada, h. 213. 
Registrasi adalah tahapan dimana produk-produk yang telah selesai produksi akan diberikan nomor untuk menyatakan bahwa produk tersebut telah memenuhi standar pembuatan.

4. Inspeksi

Inspeksi dilakukan ke pasar, swalayan atau retailretail lainnya secara berkala guna memeriksa makanan yang dicurigai berbahaya bagi kesehatan.

\section{Sampling}

Sampling merupakan kegiatan pengambilan contoh makanan yang dicurigai berbahaya yang kemudian akan diujikan ke laboraturium.

\section{Public warning}

Public warning adalah pernyataan resmi yang dikeluarkan oleh BPOM apabila ditemukan makanan yang dapat membahayakan kesehatan maupun keselamatan konsumen.

\section{Layanan Konsumen}

Layanan konsumen dibuat dengan tujuan untukk menerima aduan oleh konsumen agar nantinya konsumen dapat merasa aman dan nyaman dalam mengkonsumsi produk-produk makanan.

Berdasarkan wawancara dengan Dra. Luh Putu Witariathi, Apt. sebagai Kepala Bidang Sertifikasi dan Layanan Informasi Konsumen menyatakan bahwa pihaknya (BPOM Denpasar) sempat menarik beberapa mi instan asal Korea dari peredaran. Mi instan yang ditarik dari peredaran antara lain Nonghim Mi Instan rasa Kimchi, Nongshim Shin Ramyum dan Nongshim Neoguri Noodles. Produk-produk tersebut ditarik dari peredaran karena produk tersebut terkontaminasi dengan DNA babi pada saat proses 
produksinya, namun hal ini hanya terjadi pada 1 batch saja atau sekali produksi itu saja.

Penemuan mi instan yang terkontaminasi dengan DNA babi ini tentunya menunjukkan bahwa pengawasan yang dilakukan oleh BPOM belum berjalan dengan efektif. Sekalipun dikatakan aturan yang ditaati itu efektif, tetapi kita tetap masih dapat mempertanyakan lebih jauh derajat efektivitasnya karena seseorang menaati atau tidak suatu aturan hukum tergantung pada kepentingannya. ${ }^{9}$

Terkait pelaksanaan fungsi pengawasan BPOM tersebut telah dikeluarkan Peraturan Kepala Badan POM RI No. HK.00.05.23.1455 tanggal 24 Maret 2008 tentang Pengawasan Pemasukan Pangan Olahan, Pasal 4 mengatur sebagai berikut:

Pasal 4

Pangan Olahan yang dimasukkan ke dalam wilayah Indonesia harus memenuhi persyaratan:

(1) Telah diuji dan atau diperiksa serta dinyatakan lulus dari segi keamanan, mutu dan gizi oleh instansi yang berwenang di negara asal;

(2) Pengujian dan atau pemeriksaan sebagaimana dimaksud pada huruf a harus dibuktikan dengan serti - kasi analisis dari laboratorium yang terakreditasi;

(3) Terhadap pangan olahan sebagaimana dimaksud pada huruf a dapat dan atau diperiksa kembali di Indonesia dari segi keamanan, mutu dan atau gizi sebelum diedarkan.

Berdasarkan wawancara dengan Dra. Luh Putu Witariathi, Apt. sebagai Kepala Bidang Sertifikasi dan Layanan Informasi Konsumen, pada tanggal (16 April 2018) menyebutkan untuk pangan yang mengandung babi atau produk turunan babi, wajib mencantumkan logo mengandung babi, berupa gambar babi

9 Achmad Ali, 2009, Menguak Teori Hukum (Legal Theory) dan Teori Penelitian (Judicialprudence) Termasuk Interpretasi Undang-Undang (Legisprudence), Jakarta, Penerbit Kencana, h. 375 
dengan tulisan "MENGANDUNG BABI" berwarna merah dan harus dicantumkan pada label bagian utama.

Untuk memastikan keamanan pangan yang beredar di Indonesia, semua produk pangan yang didaftarkan wajib dianalisa cemaran fisik, kimia dan mikrobiologinya dengan parameter uji sesuai ketentuan yang berlaku. Pengujian pangan impor dapat dilakukan di dalam maupun luar negeri.

2.2.2 Peredaran Produk Makanan Impor Yang Tidak

Bersertifikasi Halal yang Merugikan Konsumen

Berdasarkan wawancara dengan Dra. Luh Putu Witariathi, Apt. sebagai Kepala Bidang Sertifikasi dan Layanan Informasi Konsumen mengatakan bahwa kendala-kendala yang dihadapi oleh BPOM dalam melakukan pengawasan terbagi menjadi kendala internal dan kendala eksternal.

Kendala internal yang dihadapi BPOM meliputi:

1. BPOM hanya berada di ibukota provinsi sehingga daerahdaerah yang jauh dari ibukota antara lain Karangasem, Klungkung, Bangli, Gianyar, Badung, Tabanan, Jembrana dan Buleleng tidak mendapat pengawasan secara maksimal.

2. Keterbatasan staff BPOM mempengaruhi pelaksanaan tugas pengawasan yang seharusnya dilakukan oleh BPOM, apalagi ditambah dengan cakupan wilayah yang sangat luas.

3. Keterbatasan anggaran juga menyebabkan pengawasan yang berjalan kurang maksimal. Anggaran yang diberikan oleh pusat kemudian akan di pos-poskan ke daerah dan merujuk pada skala prioritas yang artinya pengawasan dilakukan lebih diefektifkan sesuai dengan anggaran yang ada.

Kendala eksternal yang dihadapi BPOM antara lain:

1. Kurangnya dipatuhinya peraturan-peraturan yang ada terutama oleh pelaku usaha sehingga masih ditemukannya 
produk-produk makanan impor yang dapat membahayakan kesehatan.

2. Rendahnya kesadaran konsumen untuk melakukan laporan maupun pengaduan kepada lembaga terkait apabila ada produk makanan yang membahayakan atau merugikan konsumen. Hal ini terutama disebabkan oleh kurangnya kesadaran dari pihak konsumen itu sendiri dan rendahnya pendidikan konsumen yang ada. ${ }^{10}$

Adapun upaya-upaya yang dilakukan BPOM dalam menanggulangi kendala-kendala yang ada, antara lain:

1. Melakukan sosialisasi kepada pelaku usaha maupun konsumen. Sosialisasi kepada pelaku usaha dilakukan agar pelaku usaha menjual produk yang sesuai dengan perundang-undangan serta BPOM akan memberikan bimbingan teknis mengenai pembuatan makanan yang baik. Sosialisasi dengan konsumen juga dilakukan agar konsumen lebih berhati-hati dalam memilih produk makanan impor untuk dikonsumsi. Selain itu BPOM juga meminta bantuan pengawasan oleh masyarakat. Masyarakat memiliki peran penting, mengingat keterbatasan sumber daya manusia yang dimiliki BPOM. Bentuk pengawasan ini adalah pengawasan partisipasif dari seluruh elemen masyarakat. ${ }^{11}$

2. Kerjasama dengan institusi lainnya antara lain dengan Ditjen Bea Cukai, Dinas Kesehatan, Departemen Perdagangan serta Lembaga Konsumen Swadaya

10 A.A Gde Agung Brahmanta, 2016, "Perlindungan Hukum Bagi Konsumen Dalam Perjanjian Baku Jual Beli Perumahan Dengan Pihak Pengembang di Bali", Jurnal Kenotariatan, Fakultas Hukum Universitas Udayana, h. 208.

11 Rosita Indrayati, 2016, "Revitalisasi Peran Hakim Sebagai Pelaku Kekuasaan Kehakiman Dalam Sistem Ketatanegaraan Indonesia", Jurnal Kertha Patrika, Fakultas Hukum Universitas Udayana, h. 117. 
Masyarakat. Ditjen Bea dan Cukai bertugas untuk melakukan pengecekan dokumen importir. Selanjutnya, Dinas kesehatan bertugas untuk membantu BPOM dalam melakukan sosialisasi tentang makanan berbahaya. Kemudian departemen perdagangan bertugas untuk melakukan pemeriksaan kode registrasi yang terdapat pada kemasan produk.

\section{Penutup}

\subsection{Kesimpulan}

Berdasarkan hasil penelitian dan pembahasan, maka dapat ditarik kesimpulan sebagai berikut:

1. Pola pengawasan BPOM terdiri dari sistem pengawasan produsen dan sistem pengawasan pemerintah. Sistem pengawasan produsen meliputi good manufacturing pratices, pre market dan post market. Sistem pengawasan pemerintah diantaranya meliputi regulasi, standarisasi, registrasi, inspeksi, sampling, public warning dan layanan aduan konsumen. Pelakasanaan sistem pengawasan makanan impor yang tidak bersertifikasi halal belum berjalan secara efektif. Hal ini dapat dilihat masih terdapatnya mi instan Korea yang tercemar DNA babi (porcine) pada proses produksinya.

2. Dalam menjalankan perannya di bidang pengawasan obat dan makanan memiliki kendala internal dan eksternal. Upaya-upaya yang dilakukan BPOM dalam menanggulangi perederan makanan impor yang tidak bersertifikasi halal yang merugikan konsumen antara lain; sosialisasi, kerjasama dengan institusi lainnya.

\subsection{Saran}


1. BPOM perlu meningkatkan koordinasi pengawasan dengan instansi terkait dengan didukung peran serta masyarakat sebagai konsumen. Perlu ditingkatkan kegiatan sosialisasi dan informasi terhadap konsumen sesuai dengan Pasal 4 Undang-undang Perlindungan Konsumen agar cermat dalam memilih makanan.

2. BPOM sebaiknya membentuk kantor cabang BPOM pada seluruh wilayah administratif Provinsi Bali yang terdiri dari 8 kabupaten, karena sampai saat ini kantor BPOM Bali hanya ada di satu kota, yaitu Denpasar. Hal tersebut ditujukan agar wilayah pengawasan dan pembinaan masyarakat terhadap peredaran makanan impor bersertifikasi halal yang beredar di pasaran dapat merata ke seluruh wilayah yang ada di Bali. Lebih dipertingkat jumlah staf BPOM agar pelaksanaan tugas pengawasan dari BPOM dapat terlaksanan dengan lebih baik. Serta sebaiknya ada penambahan anggaran agar pengawasan yang dilakukan oleh BPOM lebih diefektifkan dan dioptimalkan dengan anggaran yang tersedia. 


\section{DAFTAR PUSTAKA}

\section{Buku}

Achmad Ali, 2009, Menguak Teori Hukum (Legal Theory) dan Teori Penelitian (Judicialprudence) Termasuk Interpretasi Undang-Undang (Legisprudence), Penerbit Kencana, Jakarta

Happy Susanto, 2008, Hak-Hak Konsumen Jika Dirugikan, Transmedia Pustaka, Jakarta

I Made Pasek Diantha, 2016, Metodologi Penelitian Hukum Normatif dalam Justifikasi Teori Hukum, Prenada Media, Jakarta

Soerjono Soekanto, 2008, Faktor-Faktor yang Mempengaruhi Hukum, PT. Raja Grafindo Persada, Jakarta

\section{Peraturan Perundang-undangan}

Undang-Undang tenang Kesehatan, Undang-Undang Nomor 36 Tahun 2009, Lembaran Negara Republik Indonesia tahun 2009 Nomor 144, Tambahan Lembaran Negara 5607.

Undang-Undang tentang Pangan, Undang-Undang Nomor 18 Tahun 2012, Lembaran Negara Republik Indonesia Nomor 227 tahun 2012, Tambahan Lembaran Negara Republik Indonesia 5360.

\section{Jurnal dan Internet}

A.A Gde Agung Brahmanta, 2016, "Perlindungan Hukum Bagi Konsumen Dalam Perjanjian Baku Jual Beli Perumahan Dengan Pihak Pengembang di Bali”, Jurnal Kenotariatan, Fakultas Hukum Universitas Udayana, URL: https://ojs.unud.ac.id/index.php/ActaComitas/article/v iew $/ 24953$ 
Edy Nurcahyo, 2018, "Pengaturan dan Pengawasan Produk Pangan Olahan", Jurnal Magister Hukum, Fakultas Hukum Universitas Udayana, URL: https://ojs.unud.ac.id/index.php/jmhu/article/view/42 227

Ni Putu Januaryanti Pande, 2017, "Perlindungan Konsumen Terhadap Produk Kosmetik Impor yang Tidak Terdaftar di BBPOM Denpasar", Jurnal Magister Hukum, Fakultas Hukum Universitas Udayana, URL: https://ojs.unud.ac.id/index.php/jmhu/article/view/22 288

Nurhayati, 2009, "Efektivitas Pengawasan Badan Obat dan Makanan", Jurnal Hukum, Fakultas Hukum Universitas Gajah Mada, URL: https://jurnal.ugm.ac.id/jmh/article/view/16265 Jabbar Ramdhani, Detik News, 2017, "BPOM: Ada importir Mi Samyang Dicabut Izin Edarnya Januari Lalu", URL: https://news.detik.com/berita/d-3535433/bpom-adaimportir-mi-samyang-dicabut-izin-edarnya-januari-lalu

Rosita Indrayati, 2016, "Revitalisasi Peran Hakim Sebagai Pelaku Kekuasaan Kehakiman Dalam Sistem Ketatanegaraan Indonesia", Jurnal Kertha Patrika, Fakultas Hukum Universitas Udayana, URL: https://ojs.unud.ac.id/index.php/kerthapatrika/article/ view/30089 
